\title{
Erratum to: Analysis of Genetic Diversity of Saccharum Complex Using Chloroplast Microsatellite Markers
}

\author{
${\text { Punnya } \text { Raj }^{1} \text { - A. Selvi }}^{1}$ - P. T. Prathima ${ }^{1}$ N. V. Nair ${ }^{1}$
}

Published online: 23 June 2015

(C) Society for Sugar Research \& Promotion 2015

\section{Erratum to: Sugar Tech \\ DOI 10.1007/s12355-015-0382-1}

In the original publication of the article, the text, "rest of the Saccharum spcies. Ripidium, one of....." on line numbers 19 and 20 of the abstract section was published incorrectly. The correct text should read as "rest of the Saccharum species. Erianthus sect. Ripidium, one of.....".

The online version of the original article can be found under doi: $10.1007 / \mathrm{s} 12355-015-0382-1$.

Punnya Raj

punnyaster@gmail.com

A. Selvi

selviathiappan@yahoo.co.in

P. T. Prathima

prathimasambandam@gmail.com

N. V. Nair

vijay52in@yahoo.com

1 Biotechnology Laboratory, Sugarcane Breeding Institute,

Coimbatore 641007, India 